\title{
EFFECTS OF MINERAL FERTILIZATION ON THE CHEMICAL CHARACTERISTICS OF FERRALLITIC SOIL UNDER ANANAS COMOSUS CULTIVATION IN SOUTH BENIN
}

\author{
Noé Luc YENONFAN*, Innocent N. GBAI, Jean-Marie DJOSSOU, Xavier Gomido KOOKE and Brice \\ Agossou Hugues TENTE \\ University of Abomey-Calavi, Department of Geography and Spatial Planning, Laboratory of Biogeography and \\ Environmental Expertise BP 677 Abomey-Calavi, Benin \\ https://doi.org/10.35410/IJAEB.2020.5528
}

\begin{abstract}
The aim of this research is to analyse the influence of mineral fertilization on the chemical characteristics of ferrallitic soil under conventional and organic pineapple cultivation in the municipalities of Allada, Tori-Bossito and Zè in South Benin. For this purpose, the chemical parameters (pHeau, pHKCl, C-organique, N-total, P-assimilable, and changeable basis) of pineapple-cultivated soils and pineapple-free fallow soils were determined. The two-factor analysis of variance (field types and communes) was performed using Statistical Analysis System version 9.2 software and the means were compared using the Student Newman-Keuls test at the $5 \%$ threshold. The results revealed that the carbon content is higher $(\mathrm{P}<0.05)$ in the pineapple-cultivated ferrallitic soil in the municipality of Allada compared to the pineapple-free ferrallitic fallow soil. The water $\mathrm{pH}$ of ferrallitic soils under pineapple cultivation are acidic. The high values of potassium, $\mathrm{C} / \mathrm{N}$ ratio and organic matter were recorded in the ferrallitic soils of the municipality of Tori-Bossito. Mineral fertilisation under pineapple cultivation influences the organic matter,water $\mathrm{pH}$ and phosphorus of the soil.
\end{abstract}

Keywords: Mineral fertilization, soil sample, ferralitic soil, South Benin.

\section{INTRODUCTION}

Pineapple is the second tropical fruit in the world trade after bananas and contributes to more than $20 \%$ of the world production of tropical fruits (FAO, 2015). In West Africa, Benin is the second largest producer of pineapples, after Nigeria (FAO, 2013) .Its production is booming, increasing from 222,000 tonnes in 2009 to 600,000 tonnes in 2015 (MAEP, 2015). Main fruit crop in South Benin, particularly in the Atlantic department, pineapples are cultivated by around $70 \%$ of producers who produce around $95 \%$ of the total production in Benin (Helvetas-Benin , 2008). The pineapple sector is a factor in improving living conditions not only for producers but also for traders. It offers employment to farmers and especially to women who mainly trade and process fresh fruit (Sohinto, 2008). Despite the socio-economic importance of pineapple production, this sector faces many constraints including the difficulty of exporting the pineapples produced. The proportion of fresh pineapple exported to the international market is negligible (Fassinou Hotegni et al., 2012). About $50 \%$ of the annual production is sold on the national 
market (35\% for self-consumption and $15 \%$ for processing) and the rest of the exported production is distributed as follows: $2 \%$ to the European Union, $8 \%$ in dried pineapple exported and $40 \%$ to countries in the sub-region (Nigeria, Niger, Burkina Faso, Mali etc.) (Adoho, 2017).

The municipalities of Tori-Bossito, Allada and Zè are those of the Allada plateau where pineapple cultivation occupies an important place among the various agricultural activities.

Work has been carried out on pineapple in southern Benin, by several authors, notably Sossa et al. (2014) on the characterization of pineapple (Ananas comosus (L.) Merrill) cultivation systems on the Allada plateau; Agbangba et al. (2015) and Padonou et al. (2018) on the influence of mineral fertilization on the yield and quality of pineapple. However, studies on the chemical properties of the soil under the cultivation of pineapple (Ananas comosus L. Merrill) in the producing communities in southern Benin have received very little attention from agricultural research. The purpose of this research is to analyze the influence of mineral fertilization on the chemical characteristics of ferrallitic soils under conventional and organic pineapple cultivation in the municipalities of Tori-Bossito, Allada and Zè on the Plateau Allada.

\section{METHOD AND MATERIAL}

\subsection{Study environment}

The work of this research took place in three municipalities of the Plateau of Allada namely: municipality of Allada, municipality of Tori-Bossito and Zè which constitute the study area. This study area is located in the Atlantic Department in the south of Benin, a region of great pineapple production, whose area sown are increasing from year to year. It is located between $02^{\circ} 02^{\prime}$ and $02^{\circ} 25^{\prime}$ 'east longitude then between $06^{\circ} 26^{\prime}$ and $06^{\circ} 57$ 'north latitude (Figure 1).

This work was carried out on ferrallitic soils under conventional and organic pineapple cultivation and on ferrallitic soils fallow without pineapple cultivation.

The soils that have been subject to soil samples are ferrallitic. The study area has a subequatorial climate, with four seasons including two rainy seasons (March to June and September to November) and two dry seasons (July to September and November to March). The average annual rainfall amounts vary between 1,100 and $1,400 \mathrm{~mm}$ This rainfall corresponds to the cultivation of pineapples, in comparison with the optimum necessary for cultivation located between 1,200 and 1,500 mm of rain per year (Scahier and Texido, 2001). 


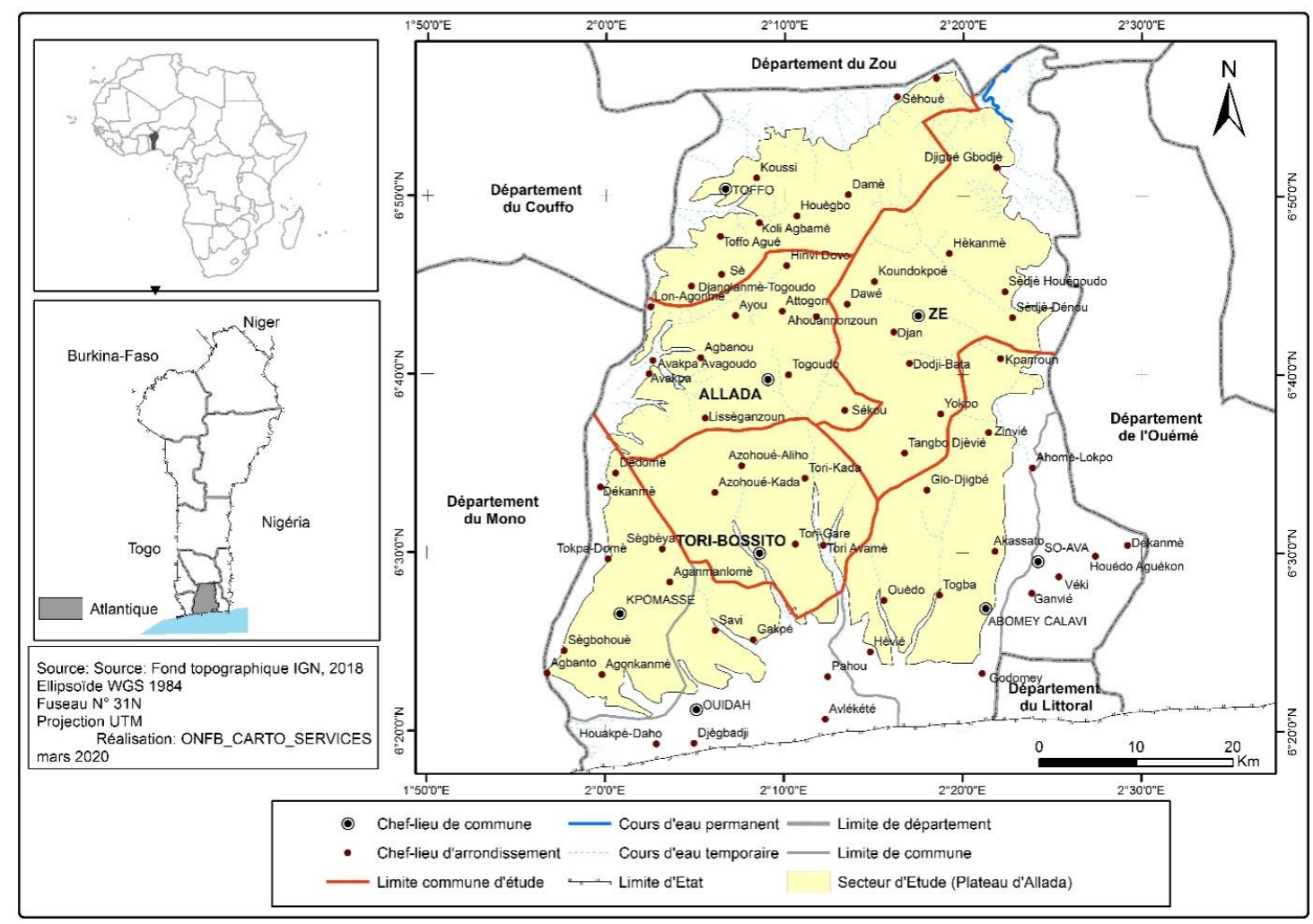

Figure 1: Geographic location of the study area

\subsection{Collection equipment}

The field equipment used consists of:

- Garmin 60 Global Positioning System (GPS) for the geo-location of fields;

- An auger for taking soil samples for analysis at Le

- A digital balance of $1 \mathrm{~kg}$ range for the measurement of soil samples;

- Polyethylene bags to store the soil samples;

- A camera for taking pictures; and

- A dhesive paper was used for labeling

\subsection{Laboratory equipment}

A BÜCHI B-324 brand Kjedhal still for the determination of total nitrogen; a $\mathrm{pH}$ meter for reading the $\mathrm{pH} ; 2 \mathrm{~mm}, 425 \mu \mathrm{m}$, and $32 \mu \mathrm{m}$ mesh screens for sieving the soil, and finally chemical reagents suitable for the analysis of soil samples.

\subsection{Study material}


The study material covers the conventional and organic pineapple fields where mineral fertilizers are used and the fallow without pineapple production and without the use of mineral fertilizers.

\subsection{Method of taking soil samples}

The 0-20 cm depth balance samples were taken on dates 10, 11 and 22 September 2019 in the municipalities of Allada, Tori-Bossito and Zè on the Plateau d'Allada. In each municipality considered on the Plateau d'Allada, three plots (conventional pineapple field, organic pineapple field and fallow without pineapple cultivation). Each plot was cut into three lots of the same area. In each batch obtained, three soil samples 0-20 cm deep were taken along the diagonal. In order to obtain representative composite samples, the carrots obtained at the layer are mixed homogeneously. A $100 \mathrm{~g}$ sample of this mixture was taken from a polyethylene bag. For each plot considered, three soil samples were taken. A total of 27 soil samples were taken from all three municipalities. These samples were conveyed to the laboratory, dried at room temperature and then sieved to $2 \mathrm{~mm}$ in order to remove coarse elements. Plate 1 below illustrates the process of taking soil samples under pineapple cultivation and under fallow without cultivation pineapple

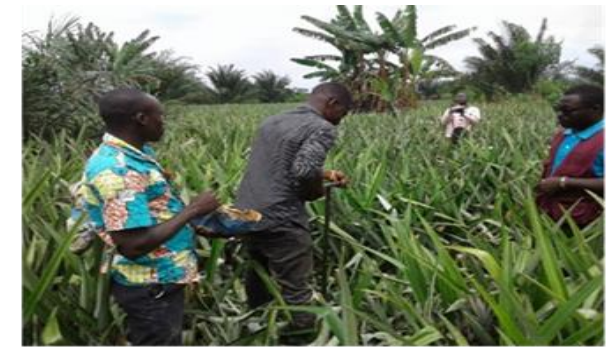

Photo1 : Prélèvement d'échantillon de sols sous culture d'ananas à Tori-Bossito Prise de vue : $Y E N O N F A N$ L., septembre 2019

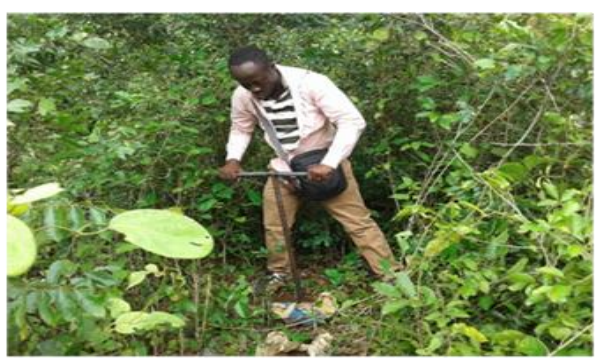

Photo 3 : Prélèvement d'échantillon de sol sous jachère sans culture d'ananas à ToriBossito

Prise de vue : KOOKE G.X., septembre 2019

Planche 1 : Prélèvements d'échantillons de sols à l'aide de la tarière sous culture d'ananas et sous jachère sans culture d'ananas

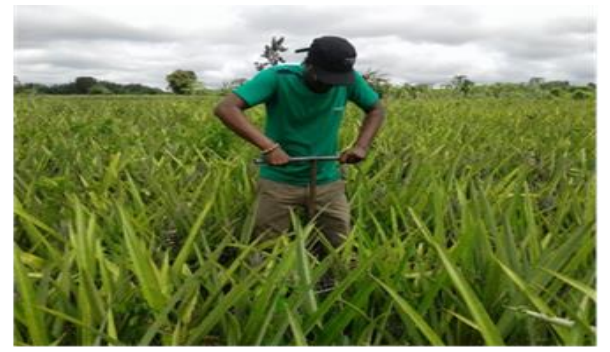

Photo 2 : Prélèvement d'échantillon de sols sous culture d'ananas à Zè

Prise de vue : $G B A I$ N.I., septembre 2019

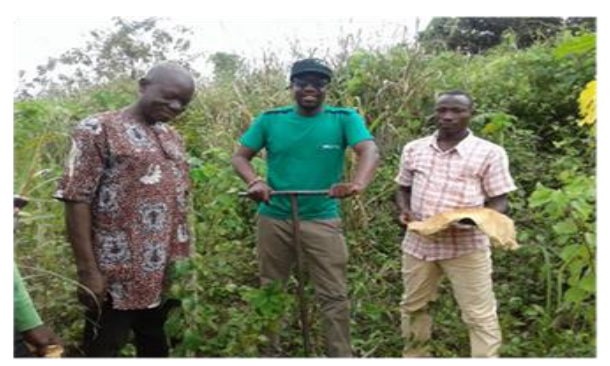

Photo 4 : Prélèvement d'échantillon de sols sous jachère sans culture d'ananas à Zè Prise de vue : DJOSSOU J. M., septembre 2019

Photos 1 and 2 of Plate 1 show an operation to collect soil samples using the auger under pineapple cultivation in Tori-Bossito and Zè respectively, and Photos 3 and 4 show this sampling operation samples of fallow soils without pineapple cultivation in these same municipalities. 


\subsection{Methods of chemical analysis}

The chemical analyzes were carried out in the Laboratory of Soil, Water and Environmental Sciences (LSSEE) of the National Institute of Agricultural Research in Benin (INRAB). These analyzes consisted in determining:

- pHeau and pHKCL: by the potentiometric method in a soil / distilled water ratio of $1 / 2.5$;

- organic carbon: by the Walkley \& Black method which consists in oxidizing the organic matter of the soil with potassium dichromate $(\mathrm{K} 2 \mathrm{Cr} 2 \mathrm{O} 71 \mathrm{~N})$ in an acid medium in the soil / $\mathrm{K} 2 \mathrm{Cr} 2 \mathrm{O} 7$ ratio of $0.25 / 10$;

- Assimilable phosphorus is extracted according to the Bray 1 method. The filtrate is colored by ammonium molybdate in the presence of ascorbic acid and the intensity of the coloration is determined by colorimetry at the wavelength of $660 \mathrm{~nm}$. The extraction solution is composed of $\mathrm{NH} 4 \mathrm{~F}$ and $\mathrm{HCl}$;

- total nitrogen: by the Kjeldahl method consisting of acid digestion followed by microdistillation. The soil is treated with sulfuric acid (H2SO4) in a soil-solution ratio of $1 / 20$ in the presence of a selenium tablet (serving as a catalyst). The distillation is carried out by steam entrainment in the presence of $20 \mathrm{ml}$ of $1 \mathrm{~N} \mathrm{NaOH}$. The distillate is collected in an Erlenmeyer flask which contains $20 \mathrm{ml}$ of boric acid and 4 drops of indicator based on methyl red. The titration is carried out with $0.1 \mathrm{~N}$ sulfuric acid (H2SO4);

- Potassium: by the method of Helmke and Sparks (Helmke and Sparks, 1996). It consists in reading the cations with an atomic absorption spectrophotometer after extraction with neutral ammonium acetate.

\subsection{Data analysis method}

The ANOVA procedure of Statistical Analysis System software version 9.2 (SAS v. 9.2) was used for statistical analyzes of the effect of mineral fertilizers. These analyzes essentially consisted of analyzes of variance with two factors (types of field, common). The mean values were compared with each other using the Student Newman Keuls test at the 5\% level.

\section{RESULTS}

2.1 Comparison of chemical characteristics of ferritic soils under pineapple cultivation and fallow without pineapple cultivation

The results of analysis of variance carried out on the characteristics of the types of fields and according to the communes are recorded in table 1 . 
Table 1: Analysis of variance (Fisher value) of the chemical parameters of the types of fields and according to the communes. The values in parenthesis represent the probabilities.

\begin{tabular}{|c|c|c|c|c|c|c|c|}
\hline Valeur de Fisher & & & & & & & \\
\hline $\begin{array}{l}\text { Source de } \\
\text { Variation }\end{array}$ & $\begin{array}{l}\text { Degré de } \\
\text { liberté }\end{array}$ & $\mathbf{N}[\%]$ & $\mathrm{C}[\%]$ & K[méq/100g] & pHeau & рНкс, & $\begin{array}{l}\text { Pass } \\
{[\mathrm{mg} / \mathrm{Kg}]}\end{array}$ \\
\hline Communes & 2 & $\begin{array}{l}1,33 \mathrm{~ns} \\
(0,2896)\end{array}$ & $\begin{array}{l}16,33 * * * \\
(<, 0001)\end{array}$ & $\begin{array}{l}7,35^{* *} \\
(0,0046)\end{array}$ & $\begin{array}{l}0,22 \mathrm{~ns} \\
(0,8044)\end{array}$ & $\begin{array}{l}0,82 \mathrm{~ns} \\
(0,4581)\end{array}$ & $\begin{array}{l}1,60 \mathrm{~ns} \\
(0,2289)\end{array}$ \\
\hline Type de champs & 2 & $\begin{array}{l}3,6^{*} \\
(0,0484)\end{array}$ & $\begin{array}{l}2,04 \mathrm{~ns} \\
(0,1593)\end{array}$ & $\begin{array}{l}1,73 \mathrm{~ns} \\
(0,2053)\end{array}$ & $\begin{array}{l}3,63 * \\
(0,0475)\end{array}$ & $\begin{array}{l}6,32 * * \\
(0,0084)\end{array}$ & $\begin{array}{l}6,21^{* *} \\
(0,0089)\end{array}$ \\
\hline $\begin{array}{l}\text { Communes*Type } \\
\text { de champs }\end{array}$ & 4 & $\begin{array}{l}0,94 \mathrm{~ns} \\
(0,4619)\end{array}$ & $\begin{array}{l}3,48^{*} \\
(0,0283)\end{array}$ & $\begin{array}{l}5,75^{* *} \\
(0,0037)\end{array}$ & $\begin{array}{l}1,80 \mathrm{~ns} \\
(0,1724)\end{array}$ & $\begin{array}{l}2,27 \mathrm{~ns} \\
(0,1013)\end{array}$ & $\begin{array}{l}1,52 \mathrm{~ns} \\
(0,2395)\end{array}$ \\
\hline
\end{tabular}

ns: $\mathrm{P}>0.05 *: \mathrm{P}<0.05 * *: \mathrm{P}<0.01 * * *: \mathrm{P}<0.001$

ns: not significant *: significant at the 0.05 threshold; **: highly significant at the 0.01 threshold; $* * *$ : very highly significant at the threshold of 0.001

The analysis of variance in Table 1 shows that apart from the carbon and potassium contents which do not vary significantly $(\mathrm{P}>0.05)$ between the types of field from one commune to another, the other chemical characteristics of the soil vary significantly and very significantly ( $p$ $<0.05$ and $\mathrm{p}<0.01)$ between the types of fields. 
Vol. 5, No. 04; 2020

ISSN: $2456-8643$

Table 2: chemical characteristics of ferrallitic soils under pineapple cultivation and fallow without pineapple cultivation

(average values \pm standard errors).

\begin{tabular}{|c|c|c|c|c|c|c|c|}
\hline Communes & Type de champ & $\mathbf{N}[\%]$ & $\mathrm{C}[\%]$ & K[méq/100g] & pHeau & рНксL & Pass[mg/Kg] \\
\hline \multirow[t]{8}{*}{ Allada } & Ananas & $0,10 \pm$ & $0,83 \pm$ & $0,09 \pm 0,01 \mathrm{a}$ & $5,51 \pm$ & $4,86 \pm$ & $21,32 \pm 4,68 \mathrm{a}$ \\
\hline & biologique & $0,00 \mathrm{a}$ & $0,05 \mathrm{a}$ & & $0,05 \mathrm{a}$ & $0,18 b$ & \\
\hline & Ananas & $0,10 \pm$ & $0,87 \pm$ & $0,09 \pm 0,01 \mathrm{a}$ & $5,51 \pm$ & $4,73 \pm$ & $18,16 \pm 4,45 a$ \\
\hline & conventionnelle & $0,02 \mathrm{a}$ & $0,08 \mathrm{a}$ & & $0,00 \mathrm{a}$ & $0,11 b$ & \\
\hline & Jachère & $0,83 \pm$ & $0,59 \pm$ & $0,08 \pm 0,00 \mathrm{a}$ & $5,84 \pm$ & $5,43 \pm$ & $10,29 \pm 0,55 \mathrm{a}$ \\
\hline & & $0,00 \mathrm{a}$ & $0,03 b$ & & $0,03 \mathrm{a}$ & $0,10 \mathrm{a}$ & \\
\hline & Moyenne & $0,10 \pm$ & $0,76 \pm$ & $0,09 \pm 0,00 \mathrm{~B}$ & $5,62 \pm$ & $5,01 \pm$ & $16,58 \pm 2,49$ \\
\hline & & $0,01 \mathrm{~A}$ & $0,05 \mathrm{~B}$ & & $0,07 \mathrm{~A}$ & $0,12 \mathrm{~A}$ & A \\
\hline \multirow[t]{8}{*}{ Tori-Bossito } & Ananas & $0,09 \pm$ & $0,92 \pm$ & $0,12 \pm 0,02 b$ & $5,57 \pm$ & $5,06 \pm$ & $15,62 \pm 3,56 a$ \\
\hline & biologique & $0,01 \mathrm{a}$ & $0,04 \mathrm{a}$ & & $0,01 \mathrm{a}$ & $0,01 \mathrm{a}$ & \\
\hline & Ananas & $0,09 \pm$ & $1,10 \pm$ & $0,23 \pm 0,03 a$ & $5,70 \pm$ & $5,05 \pm$ & $26,39 \pm 5,99 a$ \\
\hline & conventionnelle & $0,00 \mathrm{a}$ & $0,62 \mathrm{a}$ & & $0,15 \mathrm{a}$ & $0,08 \mathrm{a}$ & \\
\hline & Jachère & $0,07 \pm$ & $1,13 \pm$ & $0,09 \pm 0,01 b$ & $5,63 \pm$ & $5,26 \pm$ & $11,13 \pm 1,40 \mathrm{a}$ \\
\hline & & $0,00 \mathrm{a}$ & $0,14 \mathrm{a}$ & & $0,04 a$ & $0,12 \mathrm{a}$ & \\
\hline & Moyenne & $0,09 \pm$ & $1,05 \pm$ & $0,15 \pm 0,02 \mathrm{~A}$ & $5,64 \pm$ & $5,12 \pm$ & $17,71 \pm 3,06$ \\
\hline & & $0,00 \mathrm{~A}$ & $0,06 \mathrm{~A}$ & & $0,05 \mathrm{~A}$ & $0,06 \mathrm{~A}$ & A \\
\hline \multirow[t]{8}{*}{ Zè } & Ananas & $0,11 \pm$ & $0,87 \pm$ & $0,15 \pm 0,02 \mathrm{a}$ & $5,58 \pm$ & $5,08 \pm$ & $13,19 \pm 0,27 a$ \\
\hline & biologique & $0,00 \mathrm{a}$ & $0,05 a$ & & $0,06 a$ & $0,05 \mathrm{a}$ & \\
\hline & Ananas & $0,08 \pm$ & $0,85 \pm$ & $0,12 \pm 0,01 \mathrm{a}$ & $5,51 \pm$ & $4,96 \pm$ & $15,48 \pm 1,52 \mathrm{a}$ \\
\hline & conventionnelle & $0,01 \mathrm{a}$ & $0,01 \mathrm{a}$ & & $0,01 \mathrm{a}$ & $0,08 \mathrm{a}$ & \\
\hline & Jachère & $0,08 \pm$ & $0,78 \pm$ & $0,17 \pm 0,05 \mathrm{a}$ & $5,69 \pm$ & $5,05 \pm$ & $10,68 \pm 1,34 a$ \\
\hline & & $0,02 \mathrm{a}$ & $0,02 \mathrm{a}$ & & $0,09 a$ & $0,21 \mathrm{a}$ & \\
\hline & Moyenne & $0,09 \pm$ & $0,83 \pm$ & $0,15 \pm 0,02 \mathrm{~A}$ & $5,59 \pm$ & $5,03 \pm$ & $13,12 \pm 0,91$ \\
\hline & & $0,01 \mathrm{~A}$ & $0,02 \mathrm{~B}$ & & $0,04 \mathrm{~A}$ & $0,07 \mathrm{~A}$ & A \\
\hline
\end{tabular}

Source: Field and laboratory work, September 2019

The means followed by the same alphabetical letter of the same character and for the same factor are not significantly different $(\mathrm{P}>0.05)$ according to the Student Newman-Keuls test

It appears from the analysis of the results in Table 2 according to the Student Newman Keulhs test that there is no significant difference $(\mathrm{P}>0.05)$ between the nitrogen, assimilable phosphate 
and $\mathrm{pH}$ water contents in ferrite soils under pineapple cultivation and fallow soils without pineapple cultivation whatever the municipality. However, in the municipality of Allada, the organic carbon content is higher in the soil ferrous under pineapple culture compared to ferrallitic soil or fallow without pineapple cultivation on the one hand and that the pHKCL content is higher in ferrallitic soil fallow without pineapple cultivation compared to terrestrial or pineapple cultivation on the other hand. In terms of potassium content, this from Student Newman Keulhs shows that it is higher in solferrallitics under conventional pineapple culture compared to ferrallitic soil under fallow without pineapple culture and ferrallitic soil under organic pineapple culture in the municipality of Tori-Bossito while there is no significant difference between the potassium content in the ferrallitic soils of the municipalities of Zè and Allada regardless of the types of fields. As regards the pHKCL content, it is higher $(\mathrm{P}<0.05)$ according to the Student Newman Keulhs test in ferrallitic soil under fallow without pineapple cultivation compared to ferrallitic soils under pineapple cultivation in the municipality of Allada while it does not vary significantly $(\mathrm{P}>0.05)$ in the ferrallitic soils of the municipalities of ToriBossito and Zè whatever the types of fields.

In general, the results of the Student Newman Keuls test reveal that, the highest values of potassium and decarbon were recorded in the ferrallitic soils of the municipality of Tori-Bossito while in the ferrallitic of the municipality of Zè , it was only recorded the highest potassium value.

\subsection{Comparison of the organic matter content and the $\mathrm{C} / \mathrm{N}$ ratio of ferrallitic soils under pineapple cultivation and fallow without pineapple cultivation}

The results of analysis of variance carried out on the characteristics (Ratio C / N and MO) of the types of fields and according to the communes are recorded in table 3.

Table 3: analysis of variance (Fisher value) of the parameters ( $\mathrm{C} / \mathrm{N}$ and MO ratio) of the types of fields and according to the communes. The values in parenthesis represent the probabilities

\begin{tabular}{|lll|}
\hline \multicolumn{3}{|c|}{ Valeur de Fisher } \\
\hline $\begin{array}{l}\text { Source de } \\
\text { variation } \\
\text { Communes }\end{array}$ & MO [\%] & C/N \\
\cline { 2 - 3 } & $16,66^{* * *}$ & $19,08^{* * *}$ \\
Types de champs & $(<, 0001)$ & $(<, 0001)$ \\
\cline { 2 - 3 } & $2,04 \mathrm{~ns}$ & $2,91 \mathrm{~ns}$ \\
Communes*Type & $3,53 *$ & $3,12^{*}$ \\
de champs & $(0,1589)$ & $(0,0804)$ \\
& $(0,0270)$ & $(0,0412)$ \\
\hline
\end{tabular}


Source: Field and laboratory work, September 2019

The analysis of variance in Table 3 shows that the organic matter content and the $\mathrm{C} / \mathrm{N}$ ratio do not vary significantly $(\mathrm{P}>0.05)$ between the types of field but vary very significantly from one municipality to another. Figure 2 presents the chemical characteristic of ferrallitic soils of field types according to the municipalities

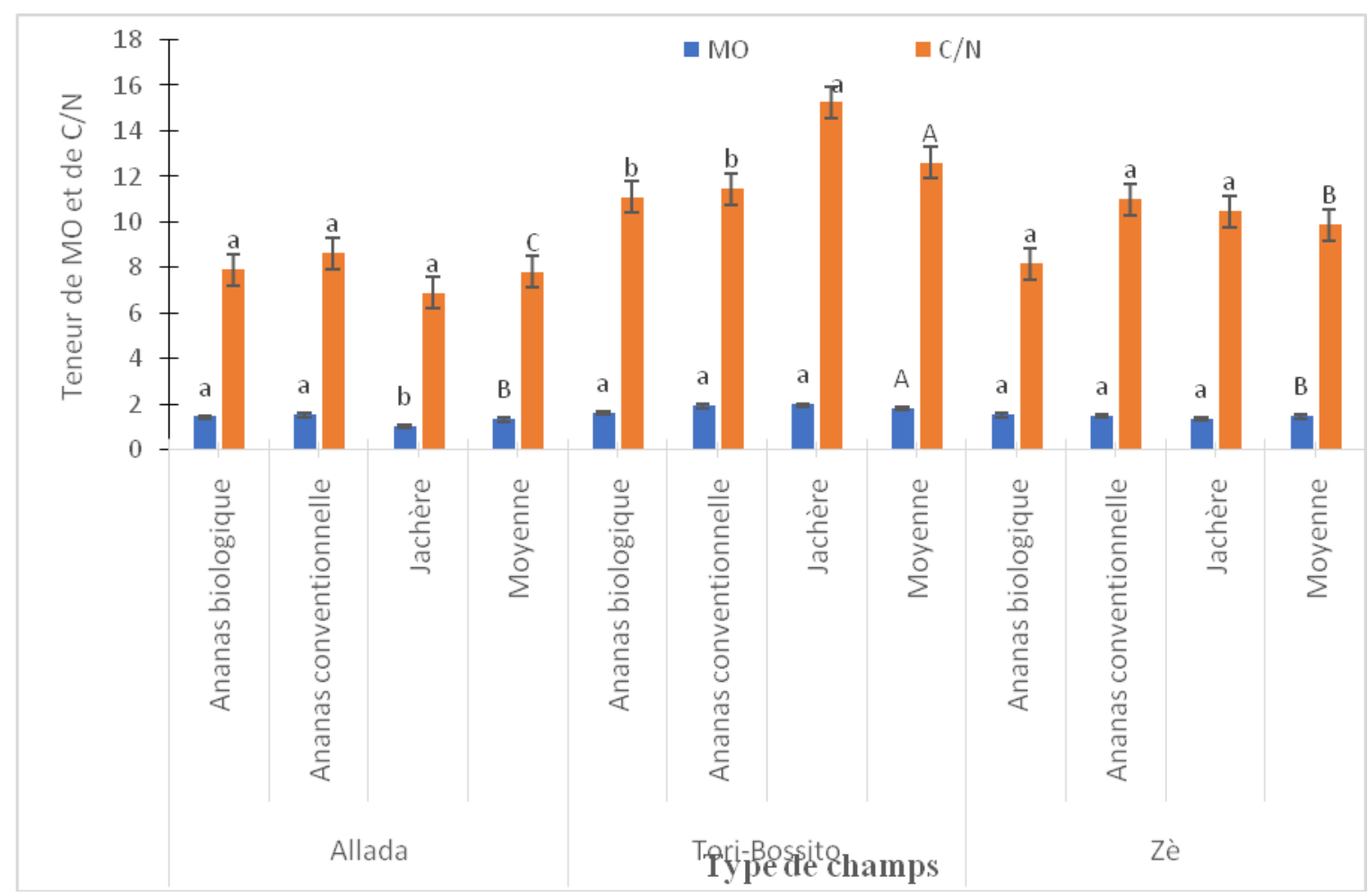

The means followed by the same alphabetical letter of the same character and for the same factor are not significantly different $(\mathrm{P}>0.05)$ according to the Student Newman-Keuls test

Figure 2: Chemical characteristics of ferrallitic soils of field types according to the municipalities

It emerges from the analysis of FIG. 2 according to the test by Student Newman Keulhs, that the $\mathrm{C} / \mathrm{N}$ ratio is significantly [ $\mathrm{p}<0.05$ ] high in the ferrallitic soil of the fallow without pineapple cultivation in the town of Tori- Bossito compared to soils under organic and conventional pineapple cultivation whereas in the municipalities of Zè and Allada, there is no significant difference [p>0.05] between the $\mathrm{C} / \mathrm{N}$ ratio in ferrallitic soils under cultivation pineapple and fallow without pineapple cultivation. Regarding the content of organic matter, it is significantly $[\mathrm{p}<0.05]$ high in ferrallitic soils under pineapple cultivation compared to ferrallitic or fallow soil without pineapple cultivation in the municipality of Allada while in the municipalities of Tori Bossito and de Zè, no significant difference [p>0.05] between the organic matter of ferrallitic soils under pineapple cultivation and ferrallitic soils fallow without pineapple cultivation was not 
noted. The highest values of organic matter and $\mathrm{C} / \mathrm{N}$ ratio were recorded in ferrallitic soils in the municipality of Tori-Bossito.

\section{DISCUSSION}

\subsection{Effects of mineral fertilizers on the chemical characteristics of soils}

The chemical characteristics of the ferrallitic soils of the fallows without pineapple production in the municipalities of Allada, Tori-Bossito and Zè on the Plateau of Alladam show respectively 5.84; 5.63 and 5.69 as pHeau values. Ferrallitic soils under pineapple cultivation have $\mathrm{pH}$ water slightly reduced by a difference of 0.06 to 0.33 compared to the $\mathrm{pH}$ water of fallows. These results corroborate those obtained by Adodo (2017) who showed that a decrease in soil $\mathrm{pH}$ can be explained by the effect of the mineralization of urea. The $\mathrm{pH}$ values obtained are suitable for growing pineapples. In fact, these $\mathrm{pH}$ values of fallow soils without pineapple cultivation as well as those under pineapple cultivation are acidic and are within the $\mathrm{pH}$ range set by $\mathrm{D}$. Baize (2000, p.119) which is 4 to 6.5 . These values correspond agronomically to an optimum favorable to the good development of the pineapple defined according to the different authors. For KE Adabe et al. (2016, p.2) the optimum is set between 4.5 and 6 and for CIRAD (2018, p.9), the soil $\mathrm{pH}$ suitable for growing pineapples is between 5 and 6.5.

The high content of organic carbon in ferrallitic soil under pineapple cultivation compared to that of ferrallitic soil under fallow without pineapple cultivation can be explained by the contribution of mineral fertilization which stimulated the decomposition of accumulated litter. These accumulated litters come from the series of weeding carried out because of the pineapple cycle which lasts about 16 months. From the results obtained, the $\mathrm{C} / \mathrm{N}$ ratios in the subsoil land fallow without pineapple cultivation are as follows: 6.88 for the municipality of Allada; 10.48 for Zè and finally 15.27 for Tori-Bossito. The ratio is low in Allada, normal in Zè and very high in Tori-Bossito. It indicates rapid decomposition of organic matter at Allada and good decomposition of organic matter at Zè (LCA, 2008), while at Tori-Bossito, it indicates the critical threshold for good decomposition and mineralization of organic matter (Saïdouet al., 2003). In contrast, the ferrallitic soils under pineapple cultivation in the sector have a $\mathrm{C} / \mathrm{N}$ ratio of between 7.88 and 11.46. This report highlights a good decomposition of organic matter. This ratio is normal without exception with ferrallitic soils under pineapple cultivation which have benefited from mineral fertilization.

According to Boyer (1982) taken up by Bello (2011), the fertility scale for assimilable phosphorus according to the Bray method and applied to the assimilable phosphorus values of the results obtained indicate on the one hand very low fertility (less than $20 \mathrm{mg} / \mathrm{kg}$ ) for ferrallitic soils under fallow without production and an average fertility (greater than $20 \mathrm{mg} / \mathrm{kg}$ ) for the assimilable phosphorus of ferralitic soils under pineapple cultivation in the municipalities of Allada and Tori-Bossito on the other hand.

\section{CONCLUSION}

At the end of this study, it is retained that mineral fertilization under pineapple cultivation has an effect on the physicochemical characteristics of ferrallitic soils in the municipalities of Allada, 
Tori-Bossito and Zè on the Allada plateau. The $\mathrm{pH}$ values of ferrallitic soils under pineapple cultivation are slightly more acidic than those of ferrallitic soils under fallow without pineapple cultivation. The comparison of organic carbon in ferrallitic soils under fallow without pineapple cultivation and in pineapple cultivation shows a low content of this element in ferrallitic fallow soil. The organic matter in ferrallitic soils in pineapple cultivation decomposes normally while that in ferrallitic soils under fallow without pineapple cultivation undergoes slow decomposition. The assimilable phosphorus is weak in ferralitic soils under fallow without pineapple production and without mineral fertilization but it is average in ferralitic soils under pineapple cultivation and under the action of mineral fertilization

\section{REFERENCE}

Adabé, K. E., Hind, S. and Maïga A., 2016. Production and processing of pineapples, Pro-agro Collection, Caméroun and the Technical Center for Agricultural and Rural Cooperation (CTA), $43 p$.

Adoho, H. M. L., 2017. Development of sustainable mineral fertilization practices for the production of smooth Cayenne pineapple in the commune of Zé in South Benin, master's thesis at the Faculty of Agricultural Science at the University of Abomey-Calavi, 58p.

Agbangba, CE, Dagbenonbakin, GD, Djogbenou, C., Houssou, P., Assea, ED, Sossa, EL, Kotomale, UA, Ahotonou, P., Ndiaga, C. and Akpo, LE, 2015.Influence of fertilization on the physicochemical and organoleptic quality of processed pineapple juice from smooth Cayenne in Benin, in Int. J. Biol. Chem. Sci. 9 (3): 1277-1288.

Baize, D., 2000. Guide to soil analyzes. 2nd edition revised and increased. INRA, Paris, 257p.

Bello, O. D., 2011. Chemical and biological characterization of production systems based on oil palm (Elaeis guineensis Jacq.) On the Adja plateau in Benin, engineer thesis in Agronomy, Faculty of Agronomic Sciences of the University of Abomey-Calavi, 86 p .

Boyer, J. 1982. Ferralitic soils: Fertility factors and soil use, Tome X, Paris ORSTOM, 392 p.

CIRAD, 2018. A short guide to pineapple production in French Guiana, manual, $36 \mathrm{p}$

FAO, 2013. Faostat - FAO statistical data bases. Roma: World Agricultural Information

FAO, 2015. FAOSTAT. Url: http://faostat3.fao.org/faostatgateway/go/to/download/Q/QC/E. Accessed on May 20, 2016.

Fassinou, N.H.V., Lommen, V.N., Vorst, V.D., Agbossou, J., Struik, E.K., 2012. Analysis of pineapple production systems in Benin. Acta Horticulturae, 928, 47-58.

Helmke, P.A, Sparks, D.L., 1996. Lithium, sodium, potassium, rubidium and cesium. In: Sparks D. L. (ed.) Methods of soil analysis. Part 3. Chemical methods. SSSA Book Series No. 5. SSSA and ASA, Madison, WI, 551-574 pp. 
HELVETAS-BÉNIN, 2008. Support for the Organic and Fair Trade Pineapple Sector: Project Document. Helvetas-Benin. Cotonou.

LCA, 2008. Practical guide: understanding and using agro-environmental analyzes

MAEP, 2015. Agricultural Sector Strategic Recovery Plan. Ministry of Agriculture, Livestock and Fisheries, Benin. Provisional version pp 52-55.

MAEP, 2015. Evolution of plant production achievements, 80p

Padonou, GE, Aholoukpè, HNS, Sossa, EL, Saidou, A. and Amadji, GL, 2018. Response of pineapple (Ananas comosus L. Merrill) to elemental mineral fertilization on ferrallitic soil in southern Benin, in Int . J. Biol. Chem. Sci. 12 (6): 2653-2666.

Saïdou, A, Kossou, D., Brussaard, L., Richards, P., Kuyper, T.W., 2008. Earthworm activities in cassava and egusi melon fields in the transitional zone of Benin: linking farmers 'perceptions with field studies. NJAS-Wageningen Journal of Life Sciences, 56-1 / 2: 123-135.

Scahier, P. and Texido R .., 2001. Pineapple. In: Raemaekers, 1500p.

Sohinto, D., 2008, Analysis of the economic profitability of pineapple value chains in Benin. Consultation report, 76p.

Sossa, E. L. Amadji, G. L., Vissoh, P. V., Hounsou, B. M., Agbossou, K. E. and Hounhouigan, D. J., 2018. Characterization of pineapple (Ananas comosus (L.) Merrill) cultivation systems on the Allada plateau in South Benin, in Int. J. Biol. Chem. Sci. 8 (3): 1030-103 